\title{
MULTILINGUALISM IN EDUCATION: THE ROLE OF FIRST LANGUAGE
}

\author{
Angela Rogers \\ Binus International School, Jakarta \\ email: angelarogers35@yahoo.co.uk
}

\begin{abstract}
This paper discusses the possibilities and effects of different language policies in schools around the world, based on recent research on second language learning and on the relationship between language and cultural identity. With reference to some of the latest findings from brain imaging in learners who speak one, two or more languages, it looks at the physical effects of bilingualism and multilingualism, and how these may be applied in teaching and in school policy to improve education. With reference to a recent survey of students in international secondary schools in Indonesia, it also discusses the cultural aspects of language use in schools and the role of language in identity. It examines the effects of learning more than one language at a young age, and of learning subjects through a language which is not the learner's first language. A large number of schools worldwide currently teach English to speakers of other languages from an early age. This paper discusses the degree to which such early foreign or second language teaching is actually useful or effective. In many parts of the world, it has also become popular to teach mainstream or even all curriculum subjects in English. Some, however, have found this to be detrimental in several ways and have therefore reverted to teaching subjects in their national language. Many are concerned about the possibility that languages with a small number of speakers are doomed to being lost and replaced by a national language, or that their national language could eventually be replaced by English. This could have important repercussions both on local cultures and on international relations, given the emotive aspects of one's first language. Vital decisions on language are frequently made based on the need for English in careers. However, it may be that the current language teaching situation is not actually succeeding in improving students' use of English or their learning in general. Moreover, there is a great risk of producing one or more generations of school leavers and graduates who cannot function beyond everyday conversation in their first language. It may be impossible for English to continue to dominate education without raising affective barriers to learning by giving a low status to local languages and cultures. In this paper, all of the above questions are discussed and researched, and several solutions to the problems arising from them are proposed.
\end{abstract}

Keywords: multilingualism, first language, second language curriculum

\section{MULTILINGUALISME DI DALAM PENDIDIKAN: PERAN BAHASA PERTAMA}

Abstrak: Makalah ini membahas kemungkinan dan dampak kebijakan bahasa yang berbeda-beda di sekolah-sekolah di seluruh dunia, berdasarkan penelitian terbaru tentang pembelajaran bahasa kedua dan tentang hubungan antara bahasa dan identitas budaya. Dengan mengacu pada beberapa temuan terbaru dari pencitraan otak peserta didik yang berbicara satu, dua atau lebih bahasa, makalah ini memperhatikan dampak fisik dari bilingualisme dan multilingualisme, dan bagaimana penerapannya dalam pengajaran dan kebijakan sekolah untuk meningkatkan kualitas pendidikan. Dengan 
mengacu pada survei terbaru terhadap siswa di sekolah menengah internasional di Indonesia, makalah ini juga membahas aspek budaya dari penggunaan bahasa di sekolah dan peran bahasa sebagai identitas. Makalah ini menelaah efek dari belajar lebih dari satu bahasa di usia muda dan efek dari mempelajari mata pelajaran menggunakan bahasa yang bukan bahasa pertama pemelajar. Banyak sekolah di dunia saat ini mengajarkan bahasa Inggris untuk penutur bahasa lain sejak usia dini. Makalah ini membahas sejauh mana keberhasilan pengajaran bahasa asing atau bahasa kedua sejak dini. Di banyak negara, penggunaan bahasa Inggris dalam pengajaran mata pelajaran utama dan bahkan semua mata pelajaran di dalam kurikulum menjadi semakin populer. Tetapi, beberapa negara menemukan bahwa cara ini berdampak buruk dalam beberapa hal dan oleh karena itu mereka kembali mengajarkan mata pelajaran menggunakan bahasa nasional masing-masing. Banyak negara khawatir tentang kemungkinan hilangnya atau tergantikannya bahasa yang penggunanya sedikit dengan bahasa nasional, atau bahwa bahasa nasional mereka akhirnya akan digantikan oleh bahasa Inggris. Hal ini bisa berdampak besar baik terhadap budaya lokal maupun terhadap hubungan internasional, mengingat adanya aspek emotif dalam bahasa pertama seseorang. Kebijakan penting tentang bahasa sering dibuat berdasarkan kebutuhan akan bahasa Inggris dalam karir. Namun, mungkin situasi pengajaran bahasa saat ini tidak benar-benar berhasil meningkatkan penggunaan bahasa Inggris siswa atau pembelajaran siswa secara umum. Selain itu, ada risiko besar dihasilkannya satu atau lebih generasi lulusan sekolah yang tidak bisa berperan selain dengan menggunakan percakapan sehari-hari dalam bahasa pertama. Mungkin mustahil untuk bahasa Inggris untuk terus mendominasi pendidikan tanpa menaikkan hambatan afektif untuk belajar, yaitu dengan memberikan status lebih rendah untuk bahasa dan budaya lokal. Dalam makalah ini, semua pertanyaan di atas akan dibahas dan diteliti, dan beberapa solusi untuk masalahmasalah yang timbul darinya akan diusulkan.

Katakunci: Multilingualisme, bahasa pertama, kurikulum bahasa kedua

We live in a multilingual world in which new languages are formed, constantly adapted, and lost. A language may dominate for decades or even centuries, only to be consigned to history when the political paradigm changes. Some are stored and studied by interested scholars and other enthusiasts, but many are lost and forgotten. Few survive the onslaught of a language with a larger and / or more powerful group of speakers. Across nations and over the centuries, different languages have become dominant, due to their speakers' use in politics, commerce and / or various educational fields which transcend borders. They have taken on the role of a lingua franca to facilitate the sharing of information and discoveries in specialised fields such as mathematics, science, religion and history, making it necessary to learn them to become a member of the powerful community in areas such as politics and education. In these circumstances, people have sometimes yielded, or been forced to surrender to the pressure of the dominant language, while some have had to fight for the status and survival of their local and national languages. Throughout history, dominant languages have come and gone. For centuries, Greek and Latin were the major languages of learning in Europe, giving a lower status to other European languages, including English, even as late as the mid-20th century, when Latin was a common requirement for entry into a university. Celtic languages used to number in the hundreds across Europe, but now only a few remain today, thanks to the efforts of their speakers. French was the major diplomatic language before the mid-20th century, and was used by educated Russians, who were often unable to speak Russian at all, regarding it as the language of peasants. English emerged as a development of West Germanic when Angles, Saxons and Jutes moved to Britain in the fifth and sixth centuries AD. Powerful though the English 
language is today, for centuries it was, like Russian, regarded as a peasant language not fit to be used in politics or education. It was only able to gain a degree of respect and acceptance through its use in literature by authors such as Chaucer and Shakespeare. Further examples of this phenomenon around the world probably run into the hundreds; many have been lost, and others and would be too numerous to mention here.

\section{MULTILINGUALISM IN THE WORLD TODAY}

Today, many countries have more than one national or official language, with any number of smaller linguistic groups within them. Governments make difficult decisions on which language or languages to promote in education and which to omit form the school curriculum. Currently, the major language of international communication and education is English. Some countries have encouraged an exclusively English-medium education, meaning there is danger of the loss or near loss of their national or local languages. Others preserve the use of their own languages in education, treating English as a separate subject. Many people feel strongly that their first language is part of their identity, yet if the current dominant language is neglected, learners may have difficulty accessing information and entering the job market. This situation poses serious questions for education policy. How can national and local languages be preserved while educating young people so that they can learn and function in the wider world? Is it more effective to teach and learn in English, students' first language, or a combination of these? How effective is multilingualism in education?

\section{THE CASE FOR MULTILINGUALISM IN EDUCATION}

While there are, of course, many successful individuals who only speak one language, a number of recent studies indicate that teaching and learning in more than one language has many positive effects on the learner. In 2009, the EU (European Union) published an extensive study of multilingualism in 29 countries, which were the 27 European Union countries plus Norway and Turkey. The huge number of cultures and linguistic groups involved in this study render its results strongly valid. It finds numerous potential cognitive advantages of using more than one language in study as well as in daily life. These include the ability to see problems from different points of view, surely an important skill in a multicultural world, as well as the likelihood that multilingualism could lead to more original and creative ways of solving problems. Some have suggested that CLIL (Content \& Language Integrated Learning, or teaching other subjects through the medium of a second or foreign language) improves language learning but not the learning of content. This study, on the other hand, concludes that learners in CLIL classes improve more rapidly than others in the acquisition of both language and content subjects.

In recent years, the use of brain imaging in medical and psychological research has been able to provide educators with a scientific view of what happens in the brain during the learning process. There is strong support for multilingualism from the field of brain imaging. Studies by Coggins et al (2004), Doidge (2007), and Osterhout et al (2008: 510) indicate that using more than one language has a great many advantages and is very likely to enhance creativity. Visual imaging studies show that, as learning progresses, physical changes occur in the brain. Upon viewing these changes in various regions of the brain, it appears that learning new languages improves certain general skills such as the ability to multi-task and to assess complex situations rapidly. Doidge $(2007,43)$ concludes that "The idea that the brain is like a muscle that grows with exercise is not just a metaphor".

Thus the use of more than one language would appear to improve overall brain function, which is surely a strong argument for multilingual pedagogy. In a brain imaging study comparing monolingual and bilingual people, Coggins et al (2004) find that "the monolingual and bilingual groups exhibited significant differences in the corpus callosum..(an area connecting the two sides of 
the brain)...... With respect to second language education, the results of this study could suggest that bilingual learning and use can have a profound effect on brain structures in general and the corpus callosum in particular". In a study of bilingual classroom instruction, Osterhout et al (2008: 510) found changes in the brain occurring even at the early stages of second language instruction: "Preliminary results from these studies indicate that classroom-based L2 (second language) instruction can result in changes in the brain's electrical activity, in the location of this activity within the brain, and in the structure of the learners' brains. These changes can occur at the earliest stages of L2 acquisition.". Thus, merely studying a language at beginner's level has advantages for the learner, changing the brain to assist learning in future.

\section{THE ROLE OF FIRST LANGUAGE}

It seems clear from the studies described above that there are great advantages in the use of more than one language in education. This leads, then, to the question of which language or languages to prioritise. Another recent study of the use of more than one language in education proposes prioritising students' first language, at least during the first six years of school, giving them a strong foundation for the learning of further languages from secondary education onwards. Pinnock \& Vijayakumar (2009) undertook research for Save the Children (an internationally renowned British development charity) and $C f B T$ (Centre for British Teachers, an organisation which has decades of experience in school teaching where English is a second language in countries such as Brunei and Malaysia). Like the European Union, this study's validity is enhanced by the large numbers of participants involved in it. This looks at very extensive worldwide data and the authors conclude that, based on their data, the best language policy for schools is "Mother-tongue-based multilingual education". This is defined as "Learnercentred, active basic education which starts in the mother tongue and gradually introduces one or more other languages in a structured manner, linked to children's existing understanding in their first language or mother tongue." This research recommends that the first 6 years of schooling are conducted only or mainly in the child's first language. The gradual introduction of new knowledge based on what is already known and has been consolidated by the learner is supported by brain imaging, and the field of education. In learning in general, new information needs to be linked to what is already known, in other words fitted into the learner's existing schemata, in order for it to be understood and recalled. Thus, the authors of this study argue that first language skills need to be built up in early life as a foundation for further learning: "Requiring a child to learn abstract or academic concepts through a process which expects them to first link new second language to the corresponding words in their first language, and then to process, retain and use that academic language - all in the same amount of schooling time that another child would be given simply to learn the concepts in their first language - involves a huge cognitive demand" (page 13).

\section{THE PACE OF LEARNING IN A SECOND LANGUAGE}

It is unfortunate that many schools expect their students to learn as quickly in a second or foreign language as they do in their first language. It is necessary here to discuss the current fashion among some groups of people of hurrying children through school so that they graduate young. Some parents and schools push children to complete school earlier than required, and use this as a measure of success and a reason to choose one school over another. They may be doing so, sad to say, for their own prestige among their social group. This becomes particularly problematic when a curriculum, with a second language as the medium of instruction may in fact require more time for successful learning rather than less, compared to a curriculum taught in the learners' first language. This raises a number of important questions. There are indeed some children who develop somewhat faster than others, and they should of course be allowed to progress beyond their normal age group's level if they have passed through the necessary intermediate phases. 
However, consider pushing children to perform tasks beyond their obvious physical capabilities, such as asking a four-year-old to reach a high shelf while standing at ground level. Clearly, this will not be possible until the child has grown taller. Similarly, pushing children to perform academic tasks which are beyond the level of their brain's development is also bound to fail until their brain has had time to develop sufficiently. This process simply cannot be hurried. Moreover, learning to perform a task in two different ways needs more time than learning to perform it in one way. Thus, where more than one language is used in education, more processing time is needed for the skills and information to be consolidated in learning so that they can be recalled and built on later as further learning takes place. The push to progress beyond what is possible in order to graduate early can only have negative consequences, leaving most learners lacking in one or more critical developmental stages. Like learning to walk, or reaching one's full adult height, learning simply takes as long as it takes, and cannot be rushed. The more there is to learn, the more time is needed, and this is bound to be the case when more than one language is involved in learning. One possible outcome may be that success is deemed to have been achieved at the expense of he first language, so that learners are unable to function in their own society beyond a basic level of everyday communication. This has far-reaching implications for the survival of the first language among the educated, and for the future careers and identity of the learners themselves.

\section{THE IDEAL AGE TO LEARN A SECOND LANGUAGE}

Contrary to a popular belief, which is based on young children's ability to copy sounds accurately, giving them a native speaker - like accent, it has been shown that children under the age of 12 are in fact the poorest language learners. This is because it is only at age 12 that people develop the "basic conceptual and linguistic framework." which the brain uses to learn language (Pinnock \& Vijayakumar, 2009). Thus, there is no need to teach a foreign language before the age of 12 , and it may be detrimental to the learner's overall progress. It has no advantage, unless of course the learner has been moved to a new linguistic community where it is necessary to use the second language.

In another article on the effects of learning a foreign language at a young age, Wang Ping (2010) refers to several studies conducted over the past 50 years, all of which have found that students who started learning a foreign language at secondary school were quickly able to catch up with those who started at primary school. There appears to be no advantage in terms of language proficiency in starting to learn a foreign language at a younger age.

\section{THE EARLY YEARS LANGUAGE CURRICULUM}

Although studies show little encouragement or foundation for teaching a second language under the age of 12 , there could be advantages of early language learning in terms of cognitive development and cultural awareness. Trawick-Smith (2010) notes that the first words small children learn are usually names of things they use regularly, such as toys, as well as socialising words such as hello, goodbye, how are you?, etc. It is recommended that caregivers and teachers who normally use a child's second language say these types of words in the child's first language as well, to help the child link the concepts to those in the first language, as well as allowing for the fact that children need more time to process more than one language. It is also noted that word order is likely to become confused in bilingual children, so adults should gently correct this by rephrasing any errors that have been spoken.

Referring to pre-school education, Trawick-Smith says: "Children should be exposed to the expressive media - art, music, storytelling, literature and drama - of their own cultures." Bilingual programs "will enhance the communicative competence of all students." A multilingual environment is recommended, in which teachers should "make an effort to become conversant in the primary languages of all children in their 
classrooms." Primary school pupils are still developing an understanding of the rules of their first language(s) and teachers should discuss these with them overtly. Bilingual children should be encouraged to speak and read both of their languages, which will help them learn to distinguish clearly between the two. Overall, the second language and the culture that comes with it should be regarded as adding to the child's knowledge and development rather than replacing their first language and culture.

\section{PRACTICAL PROBLEMS}

In practical terms, however, mother-tongue based education is difficult to realise, as many countries are multilingual and / or have immigrant children with different first languages in their classrooms. Teachers cannot all be expected to be fluent in several languages. Indonesia is a good example, where the regional language and culture are usually taught as a separate subject, while teaching is otherwise conducted in the national language, Indonesian. People generally accept the use of Indonesian in formal situations, while maintaining their first language for home, family, and transactions in their local area. Clearly, this could lead to the loss of the higher culture of these minority languages if parents and schools do not include them at some point in the curriculum, or if these languages and cultures are given a low status. The question for educators and governments around the world is whether or not such a loss should be avoided and, if so, whether they should make efforts to rescue minority languages and cultures from oblivion.

\section{SUCCESSFUL MULTILINGUAL EDUCATION}

Various countries are in fact dealing positively with multilingualism and the preservation of minority languages. In the British Isles, while English is the mother tongue of the vast majority, there are still native speakers of Celtic languages in Scotland, Ireland and Wales. In 1851 , Welsh was spoken by $90 \%$ of its population. In the late 19 th and early 20 th centuries, children were forced to speak English and punished for speaking Welsh in schools. Today, according to the Welsh Assembly Government website (May 2010), Welsh is still the first language of 575,730 people, or $20.5 \%$ of its population. Steps are being taken to increase the number of Welsh speakers, and government policy is focused on a bilingual Wales. In recent years, primary schools in Wales have used Welsh alongside English, with the aim of children being fully bilingual by the time they enter secondary school. There have been Welsh-medium schools up to lower secondary level for 50 years. Now, a move to foster the Welsh language and culture further has led to an initiative to provide secondary and higher education in Welsh. Non-native speakers of Welsh may attend English-medium schools but may also learn to function bilingually, with 11 years of studying Welsh included in the school curriculum. This example shows that a determined government and people can keep their language alive while continuing to use English. Since this is possible within the UK, right next door to English, the current dominant language, it can certainly be achieved in other parts of the world.

An inspiring example of a successful multilingual country is Switzerland, which has four official languages, namely Swiss German, French, Italian and Romanche. Schools generally teach subjects in the dominant language of their district, though some areas teach part of the curriculum in English. Students learn one or more of the other national languages, as well as English, which is often used between speakers of, say, French and Swiss German, thus not giving any of the national languages priority over the others. While the role of English is still under discussion, no one argues that it should replace the native languages of Switzerland's people; it is merely a practical and acceptable tool of communication.

Singapore is another example of a country with users of several languages, where Malay is the official language, but English is the lingua franca for most of the population. While most schools teach content mainly in English, with Malay, Tamil and Mandarin as separate subjects, there are neighbourhood schools teaching primary content in the native 
tongues, and in 2010 the government have said they will not abandon their multilingual policy. Thus, learners are given a firm foundation for learning in their first language, with respect for their cultural identity, as well as a good knowledge of a second language so that they can function in the globalised world in the future.

In Malaysia, language policy has varied over recent decades. Again, it is a question of teaching all or parts of the curriculum in English so as to provide learners with the international language skills they need, while at the same time preserving pride in their own language and cultural identity. Resistance to using a language is a common barrier to learning among those who feel that their own culture is being oppressed by that of a more dominant one. Where primary school children are taught mathematics and science through English, in Malaysia and other countries where English is a second or foreign language, MacKinnin (2008) notes a common "problem of identity with parents feeling children will lose their social identity because of English." There are numerous examples from around the world of this problem being dealt with through bilingual education. It is not impossible to allow for both if positive action is taken. As discussed above, even within the United Kingdom, Wales has developed successful bilingual policies to preserve its native language and culture while continuing to use English and live alongside English culture.

The above are only a few examples of successful bilingual and multilingual countries, in a world rich in languages and cultures which should surely not be lost in the rush to enhance global communication. Bilingualism and multilingualism appear to be the norm and the best way forward.

To overcome the perception that certain languages and cultures are inferior to others, while continuing to teach English as an international language, McKay (2003) advocates including topics on local culture in the English curriculum, using a methodology appropriate to the local context, if possible with a bilingual teacher. Thus, in an English language class, there is no reason why the topics cannot be about local issues, national literature or regional history, instead of (or in addition to) topics from textbooks based in the United Kingdom or the United States. If English is considered a lingua franca, it makes sense both practically and culturally to practise it with topics the students are actually likely to talk about. In discussing filters that block learning, Rinvolucri (2007) finds that one of these is cultural: "... a major filter which may halt the use of teaching techniques is the cultural one." Educators should be aware of this when producing or selecting materials for particular groups of students. An article by Greil (2004) at Chulalong Korn University in Thailand, recommends that "materials need to be inclusive of representations of the learner's own culture from different perspectives that specifically relate their culture to other cultures in various ways........ Based on this, learners will eventually be able to express these ideas in English and learn to communicate effectively in intercultural situations." It is surely beneficial and motivating if learners can explain aspects of their own culture to people from other cultures.

Some argue that a language cannot be separated from its culture. Yet culture is not static, but develops and changes over time and incorporates different influences. It is not culture itself, but the view people have of it, which decides how acceptable or desirable the use or non-use of a language is. English may be regarded variously as the language of Shakespeare, of the people of England, of the people of ex-British colonies, of colonial oppression, of highly educated experts, of international business, of popular culture or of cultural oppression. Parents may tell their child to speak English in order to enhance their future job prospects, or not to speak English in order to preserve the use of their first language. When the last speaker of a minority language dies, some mourn the loss of its stories and songs, while others are content to consign it to history, depending on their views on language and culture. In considering school language policy, it is therefore important to raise awareness of these issues, promoting tolerance and understanding of people's linguistic sensitivities while 
providing learners with the knowledge of the languages they are likely to need in practice.

It is certainly possible to manage more than one language during a lesson. Some argue that a second or third language will not be acquired properly or at all if learners are permitted to use their first language during language lessons. While there is a case for maximising practice in lessons if they are the only time students use the target language, it does not mean it is necessary to ban the use of learners' first language(s) altogether. It will still remain in their thoughts, and their brains will make comparisons between the two languages, so it may as well be used overtly where comparisons are useful.

In considering language policy as imposed by higher authorities, it is also important to look at the views of the learners, since affective factors are known to influence learning. With this in mind, a questionnaire (Rogers, A., 1998) was given to students aged 16 - 16 in 6 English-medium international upper secondary schools in Jakarta and Bandung, Indonesia. Students came from 16 countries, about $75 \%$ of whom were Indonesian. When asked which cultures they felt they belonged to, they were given the choices "my parents'", "international", and "other (specify)". Of the 234 responses received, 99 chose "my parents" only, 74 chose "my parents"' and "international", 41 chose "international" only, 9 chose "other" only, 8 chose "my parents" and "other", and 3 chose all three options. Thus, among these students, identity is quite strongly influenced by parents. Interestingly, "other" cultures included Indonesian regional cultures: Javanese, Sundanese, Toraja, Manado, and Batak, indicating that regional identity remains strong. Some also specified religions under "other": Catholic, Christian, Moslem, and Confucian. Significantly, the rest of the survey and follow-up interviews with some respondents indicated that these students did not strongly identify culture with language. For example, many felt they were Chinese by culture and should celebrate the Lunar New Year, but were happy to speak English and not use Chinese. This opens the door on another area for research - how strongly are languages identified with their related cultures?

\section{CONCLUSION}

Based on all of the above, it appears that multilingualism is the best way forward in education in an inter-connected world. There have always been local, regional, national and international languages, and this will continue to be the case. To ensure the preservation of local cultures and identities, a strong will and relevant policies are necessary. Parents can pass these down to their children, who are likely to accept them if the problem of low status is dealt with.

While it may be desirable where more than one language is used on a regular basis, it is certainly not necessary to begin teaching a foreign language before the age of 12 , when the brain is more developed and better able to cope with different languages. The use of more than one language is advantageous. It causes changes in the brain that would appear to lead to improved skills in some areas such as seeing problems from different points, dealing with complex issues, and multitasking. This is true even when learning a new language only at elementary level. Forbidding the use of the first language in second language classrooms is detrimental to learning, though of course sufficient time must be allocated to practice in the target language.

Young learners should be helped to develop their first language (or languages if bilingual) as a framework for learning other languages. Teachers and parents should help them by overtly comparing the differences between the languages they are learning, gently correcting word order and social language such as greetings, thanks, and so on. Multilingualism in education would therefore appear to be the best way forward for everyone.

\section{REFERENCES}

Doidge, N. (2007). The brain that changes itself. Penguin, London, 2007

Greil, T. (2004). Cultural representations and references in English textbooks used at 
Indonesian Journal of Applied Linguistics, Vol. 4 No. I, July 20 I4, pp. I-9

secondary school in Thailand: a Quantitative analysis. PASAA, 35, pp. 3550.

MacKinnon, I. (2003). Immersion is a difficult lesson, in The Guardian Weekly, 18 Jan 2008

McKay, S. (2003). Teaching English as an international language: the chilean context, in ELTJ 57(2)

Osterhout, L., Poliakov, A., Inoue, K., McLaughlin, J., Valentine, G., Pitkanen, I., et al. (2008). Second language learning and changes in the brain. Journal of

Neurolinguistics, 21, pp. 509-521.
Pinnock, H., \& Vijayakumar, G. (2009). Language and education: the missing link, Save the Children \& CfBT Trust, 2009

Rogers, A. (2008). Questionnaire on cultural identity, survey form and results. Available from angelarogers35@yahoo.co.uk, 2008

Trawick-Smith, J., (2010). Early Childhood Development: a Multicultural Perspective, Upper Saddle River, New Jersey, Available on wps.prenthall.com) Wang, P. (2010). An early start, in English Teaching Professional, Issue 68. 